\title{
Unlocking the Barriers to Women and Minorities in Computer Science and Information Systems Studies: Results from a Multi-Methodolical Study Conducted at Two Minority Serving Institutions
}

\author{
Nicole Buzzetto-More and Ojiabo Ukoha \\ University of Maryland Eastern Shore, \\ Princess Anne, MD, USA
}

\author{
Nabuzzetto-more@umes.edu; \\ oukoha@umes.edu
}

\author{
Narendra Rustagi \\ Howard University, \\ Washington, DC, USA
}

nkrustagi@yahoo.com

\section{Executive Summary}

The under representation of women and minorities in undergraduate computer science and information systems programs is a pervasive and persistent problem in the United States. Needed is a better understanding of the background and psychosocial factors that attract, or repel, minority students from computing disciplines. An examination of these factors is the focus of this multimethodological study that has been conducted over three phases with three separate populations.

During phase 1, a survey was administered to students, who were non computer science or information systems majors, enrolled in computer applications courses at both a public and a private Historically Black Universities located in Maryland. The purpose was to examine whether a correlation existed between institutional type and access, education, counseling, and exposure to computing and/or information systems. Analysis of the data found that the participating students came to college with little information about computer science (CS) and information systems (IS) as fields of study. However, a significant disparity was found when institutional type was considered. According to the findings the students attending the private minority-serving institution reported greater access to technology, skill levels, and computing studies prior to entering college.

In the second phase of the study, a satisfaction survey was administered, to students majoring in computer science at the public Historically Black University. The purpose was to examine the pre-college preparedness of minority students and whether differences would exist between the responses of the male and female participants. The respondents reported that they did not come to college with the adequate programming skills and/or prior training to succeed as a CS major, with

Material published as part of this publication, either on-line or in print, is copyrighted by the Informing Science Institute. Permission to make digital or paper copy of part or all of these works for personal or classroom use is granted without fee provided that the copies are not made or distributed for profit or commercial advantage AND that copies 1) bear this notice in full and 2) give the full citation on the first page. It is permissible to abstract these works so long as credit is given. To copy in all other cases or to republish or to post on a server or to redistribute to lists requires specific permission and payment of a fee. Contact Publisher@InformingScience.org to request redistribution permission. females found to be less prepared than males.

In the third phase of the study, a focus group was held with CS students in order to consider changes that would increase the enrollment and retention of underrepresented students. The participants suggested that the addition of bridge programs, increased scholarship opportunities, and greater academic support would increase the enrollment, 
success, and retention of underrepresented students in CS and IS majors.

Keywords: HBCU, Minority Learners, Females in Information Technology, Under-Represented Groups in IT

\section{Literature Review}

It is projected that from 2008 to 2016 there will be a $29 \%$ increase in workforce demands for computer system analysts, a 37\% increase in demand for jobs for database administrators, and a $38 \%$ increase in the availability of jobs for software engineers (U.S. Department of Labor, 2005). Despite increasing demands, women and minorities remain underrepresented in computing fields. This has become a cause for significant concern echoed by a study of corporate executives (Delos, 2008) that found that the lack of minorities and women in computing professions is causing a talent deficit. The executives surveyed blamed the pre-college school system for contributing to the low representation of women and minorities in science and technology fields by not exposing learners to computing through course offerings and/or career counseling.

Furthermore, Young (2004) reported that our perception of student computer skills may be inflated. Young's charge was echoed by Wallace and Clariana (2005) who found that incoming college students lack the necessary computer knowledge, skills, and abilities to pursue undergraduate degree programs that are dependent on strong computing skills.

The National Science Foundation (NSF) examined the population of students who earned computing and/or technology degrees in 2005. According to the NSF (Chute, 2009), only $25 \%$ of the 2005 graduates nationwide were women while $75 \%$ were men. When race was considered, only $10 \%$ of the 2005 graduates were Black.

Further, the enrollment of underrepresented groups in CS and IS programs continues to decline at a significant rate (Clinging, 2006). Clinging (2006) explains that this is influenced by a bias where low expectations foster diminished confidence and reduced success for women and minorities considering and/or attempting to study computing.

Compounding the problem is the lack of technology professionals acting as role models and limited exposure to computing professions. Chute (2009) explained that female and minority students who have not been exposed to family members who are successful in technology-related fields are unlikely to be scheduled for math or computer science classes in high school. This was echoed at a 2005 conference held by the NSF (National Science Foundation [NSF], 2005) that reported that many current science, technology, engineering, and math (STEM) professionals had family connections or other points of contact in STEM fields that helped to influence and support their decision to select and persist in STEM studies. The result is that underrepresented minority learners who lack family connections and other points of contact are at a disadvantage due to the lack of role models and support.

The digital divide remains a significant concern in the United States, with race/ ethnicity, income level, and education contributing to inequalities with the use of computers and reliable and expedient access to the internet (Morgan \& VanLegen, 2005). Sax, Ceja, and Teranishi (2001) conducted a nationwide survey of college freshmen and found that level of technological preparedness varied significantly by race, class, and academic background. They explained that these technological disparities are a hindrance to students' academic success. Further, a 2007 study of 748 freshmen students at two public HBCUs, (Buzzetto-More \& Sweat-Guy, 2007) found that while the number of students having studied computers had grown it was still significantly lower than what had been reported in the studies conducted at majority serving institutions.

Another problem is that when female and minority students arrive on college campuses they find a lack of women and minority faculty in STEM areas. Between 2002 and 2007, the number of 
underrepresented faculty in the top 100 departments for science and engineering increased by only 0.5 percent rising to 5 percent (Nealy, 2007). Nealy explains that "Underrepresented minorities are projected to constitute almost 32 percent of the American population by 2020; therefore, proactive steps should be taken now in order to insure that the proportionate inclusion of such a large part of the population in science and engineering, throughout all levels of academia," (Nealy, 2007, p. 1).

The American Association for the Advancement of Science (AAAS) has stressed the urgency of the situation by releasing a call to action for Congress to continue to put policies in place that help to increase participation among underrepresented groups in STEM (Nealy, 2007). The AAAS explains that a failure to remedy the situation will prove injurious for American innovation.

The Commission on the Advancement of Women and Minorities in Science, Engineering, and Technology (Lazowska, 1999) made recommendations to introduce programs that are focused on increasing minority participation in computing that include:

- professional development and mentoring programs;

- programs to educate women and minorities about computer science and to recruit them to the field and remedy limited exposure to computing in grade school and high school;

- a national campaign to change the image of computer scientists and engineers to address the negative impact of stereotypes; and

- collection of better data on the status of women and minorities in computer science.

One mechanism that has been introduced to meet the needs of under-prepared incoming college students is residential summer bridge programs that have been created and primarily, but not exclusively, prepare under-represented students for success in STEM majors. Customarily, they are focused on building mathematics, computing, time management, and study skills in order to increase a student's likelihood to persist through graduation in STEM majors. Their efficacy has been supported by a number of research studies (Ami, 2001; Orama, 2002; University of California Santa Cruz Basking College of Engineering, 2005) that have found that they are successful in increasing student retention and success.

The National Science Foundation is one agency that aggressively supports efforts to increase diversity in STEM disciplines by providing grants to Historically Black Colleges and Universities (HBCUs) on the undergraduate and graduate level. This has served as a call to action to HBCUs to develop programs and conduct research designed to address the lack of women and minorities in STEM. Further, the NSF has outlined specific research topics that must be explored. Among these topics are research on the social and psychological factors that contribute to individual choices to study a STEM discipline and research on practices in such areas as recruitment and retention.

\section{Background}

Founded in 1886, the University of Maryland Eastern Shore (UMES) is a Historically Black, 1890 land grant institution. It is a member of the University system of the State of Maryland, the U.S. state with the highest population of African Americans. UMES primarily serves first generation, low income, and minority learners. The student population is approximately 4500 , with a student body that is approximately $78 \%$ African-American, $9.6 \%$ white, $1.4 \%$ Hispanic, and $11 \%$ international, primarily coming from the continent of Africa and/or from the Caribbean region. The gender distribution of the University is $64 \%$ female and $36 \%$ male. The freshmen-tosophomore retention rate is $71 \%$, and the graduation rate is $41 \%$. The average GPA of the fall 2007 freshmen class was a 2.75, and the average combined math and verbal SAT score was an 
817. The school was ranked $31^{\text {st }}$ among HBCUs in 2009 and in-state tuition was $\$ 6082$ for the 2009-2010 academic year. Finally, the acceptance rate for applying students is $62.4 \%$ with the majority of students coming from the Mid-Atlantic region.

Founded in 1867, and located in Washington, D.C., Howard University is the only Historically Black University among 151 institutions that holds the Carnegie Doctoral/Research extensive classification. As the oldest HBCU, and the number one producer of African American Ph.D.s in the nation, Howard is considered by most to be the most prestigious HBCU. The student population is approximately 10,000 with 7,000 enrolled in undergraduate degree programs. The undergraduate tuition rate for 2009-2010 was $\$ 16,075$ and the mean combined math and verbal SAT score of the 2009 incoming freshmen class was 1082. Approximately, half of Howard's students come from the Mid-Atlantic region.

\section{Methodology}

A multi-methodological approach was taken during this study with two separate populations being considered. Additionally, the study was divided into three distinct phases.

During phase 1, a survey designed to measure student experience and level of comfort with computing, computer science, and computer information systems was administered, via an online survey tool, to 310 students who were non CS or IS majors, enrolled in computer applications courses at two Historically Black Universities. The data was entered into SPSS and examined with respect to three hypotheses. The first and second hypotheses considered the impact of institutional type.

$\mathrm{h} 1$ : Students attending a private minority-serving institution are more likely to come to college having previously studied computing then students enrolled at a public minorityserving institution.

h2: Students attending a private minority-serving institution have greater ownership of, and access to, technology.

The third hypothesis considered guidance and advisement.

h3: Minority students are unlikely to be counseled about computer related majors prior to college.

In the second phase of the study, a survey was administered, using the same online survey mechanism, to 52 students majoring in computer science at the public HBCU. The goal was to examine pre-college preparedness and overall satisfaction with respect to computing as a discipline. Additionally, male and female responses were compared. The data was examined with respect to a two hypotheses that considered the preparedness of minority CS students.

h4: Females attending a minority-serving institution are less likely to have received exposure to, and counseling about, computing than males.

h5: Students attending a minority serving institution do not come to college prepared for success as a computing major.

Finally, in the third phase of the study a focus group was held with 15 CS students. The goal was to gather suggestions for increasing the enrollment and retention of underrepresented students in CS and IS majors. 


\section{Findings}

\section{Phase 1}

The survey was taken by 310 students. The number of respondents from UMES (233) exceeded the number of respondents from Howard University (79). Additionally, there were slightly more female respondents $(57 \%)$ then male respondents $(48 \%)$. These results are typical of HBCUs where the enrollment of females traditionally and consistently exceeds that of males.

The most common college major reported was business (accounting, marketing, administration, international business, insurance, or finance) which represented $66 \%$ of the respondents. The full distribution of majors is represented in Table 1.

Table 1: Distribution By Major

\begin{tabular}{lcc}
$\begin{array}{l}\text { Business (Accounting, Marketing, Administration, } \\
\text { International Business, Insurance, or Finance) }\end{array}$ & 204 & $66 \%$ \\
\hline $\begin{array}{l}\text { Computer Science } \\
\text { Information Systems }\end{array}$ & 5 & $2 \%$ \\
\hline Math/Engineering & 0 & $0 \%$ \\
\hline Natural or Health Science Related & 3 & $1 \%$ \\
\hline Fine Arts/English/Communications & 21 & $7 \%$ \\
\hline Criminal Justice/Sociology/Psychology/Education & 5 & $2 \%$ \\
\hline other not listed & 35 & $11 \%$ \\
\hline Total & 36 & $12 \%$ \\
\hline
\end{tabular}

Studies have shown that level of technological preparedness varies significantly by race and economic status (Sax, et al., 2001). As a result, prior experience studying computing was considered. Most students (67\%) said that they studied computers in middle school. When the colleges were compared, however, students at Howard were more likely to say that they studied computers in middle school, at $84 \%$, compared to the $61 \%$ reported by the UMES students. Similar results were found when students were asked if they studied computers in high school. The average was $78 \%$ with Howard students reporting $89 \%$ and the UMES students reporting $75 \%$. Participants were asked to respond to the statement, "I came to college with the computer skills that I need to succeed in college." According to the results, most students came to college with the computer skills that they needed to succeed (67\%). When the schools were compared, the Howard students were more likely to be in agreement that they came to college with the computer skills necessary to in their studies (see Table 2). The comparative data was used to examine hypothesis 1 and the results supported the hypothesis.

h1: Students attending a private minority-serving institution are more likely to come to college having previously studied computing then students enrolled at a public minorityserving institution. 


\begin{tabular}{|c|c|c|c|c|c|c|}
\hline \multicolumn{7}{|c|}{ Table 2: Prior Computing Education } \\
\hline \multicolumn{7}{|c|}{ Did you study computers in middle school? } \\
\hline & \multicolumn{2}{|c|}{ UMES } & \multicolumn{2}{|c|}{ Howard } & \multicolumn{2}{|c|}{ COMBINED } \\
\hline Yes & 139 & $61 \%$ & 66 & $84 \%$ & 205 & $67 \%$ \\
\hline No & 88 & $39 \%$ & 13 & $16 \%$ & 101 & $33 \%$ \\
\hline Total & 227 & $100 \%$ & 79 & $100 \%$ & 306 & $100 \%$ \\
\hline \multicolumn{7}{|c|}{ Did you study computers in high school? } \\
\hline & \multicolumn{2}{|c|}{ UMES } & \multicolumn{2}{|c|}{ Howard } & \multicolumn{2}{|c|}{ COMBINED } \\
\hline Yes & 174 & $75 \%$ & 70 & $89 \%$ & 244 & $78 \%$ \\
\hline No & 58 & $25 \%$ & 9 & $11 \%$ & 67 & $22 \%$ \\
\hline Total & 232 & $100 \%$ & 79 & $100 \%$ & 311 & $100 \%$ \\
\hline \multicolumn{7}{|c|}{ I came to college with the computer skills that I need to succeed in college. } \\
\hline & \multicolumn{2}{|c|}{ UMES } & \multicolumn{2}{|c|}{ Howard } & \multicolumn{2}{|c|}{ COMBINED } \\
\hline Strongly Disagree & 6 & $3 \%$ & 0 & $0 \%$ & 6 & $2 \%$ \\
\hline Disagree & 25 & $11 \%$ & 5 & $6 \%$ & 30 & $10 \%$ \\
\hline Neutral/Undecided & 54 & $23 \%$ & 10 & $13 \%$ & 64 & $21 \%$ \\
\hline Agree & 86 & $37 \%$ & 38 & $50 \%$ & 124 & $40 \%$ \\
\hline Strongly Agree & 60 & $26 \%$ & 24 & $31 \%$ & 84 & $27 \%$ \\
\hline Total & 231 & $100 \%$ & 77 & $100 \%$ & 308 & $100 \%$ \\
\hline
\end{tabular}

Computer ownership was examined. Students were asked if they had a computer at home during middle school. While most said yes (77\%), there was a significant difference between the two schools. Students were also asked if they had a computer at home during high school. Most said yes (77\%); however, there was a significant difference between the two schools (see Table 3).

\begin{tabular}{|c|c|c|c|c|c|c|}
\hline \multicolumn{7}{|c|}{ Table 3: Computer Ownership During Childhood } \\
\hline \multicolumn{7}{|c|}{ Did you have a computer at home during middle school? } \\
\hline & \multicolumn{2}{|c|}{ UMES } & \multicolumn{2}{|c|}{ Howard } & \multicolumn{2}{|c|}{ COMBINED } \\
\hline Yes & 164 & $71 \%$ & 76 & $96 \%$ & 240 & $77 \%$ \\
\hline No & 68 & $29 \%$ & 3 & $4 \%$ & 71 & $23 \%$ \\
\hline Total & 232 & $100 \%$ & 79 & $100 \%$ & 311 & $100 \%$ \\
\hline \multicolumn{7}{|c|}{ Did you have a computer at home during high school? } \\
\hline & \multicolumn{2}{|c|}{ UMES } & \multicolumn{2}{|c|}{ Howard } & \multicolumn{2}{|c|}{ COMBINED } \\
\hline Yes & 200 & $88 \%$ & 74 & $94 \%$ & 274 & $90 \%$ \\
\hline No & 27 & $12 \%$ & 5 & $6 \%$ & 32 & $10 \%$ \\
\hline Total & 227 & $100 \%$ & 79 & $100 \%$ & 306 & $100 \%$ \\
\hline
\end{tabular}


All Howard University respondents (100\%) said that they had internet access at their home/primary residence compared to the $91 \%$ reported by UMES students. Furthermore, when asked whether they go online daily almost all $(99 \%)$ of Howard students said yes compared to $85 \%$ of the UMES respondents (see Table 4 ).

\begin{tabular}{|c|c|c|c|c|c|c|}
\hline \multicolumn{7}{|c|}{ Table 4: Internet Access and Use } \\
\hline \multicolumn{7}{|c|}{ Do you have internet access at your home/ residence? } \\
\hline & \multicolumn{2}{|c|}{ UMES } & \multicolumn{2}{|c|}{ Howard } & \multicolumn{2}{|c|}{ COMBINED } \\
\hline Yes & 212 & $91 \%$ & 76 & $100 \%$ & 288 & $94 \%$ \\
\hline No & 20 & $9 \%$ & 0 & $0 \%$ & 20 & $6 \%$ \\
\hline Total & 232 & $100 \%$ & 76 & $100 \%$ & 308 & $100 \%$ \\
\hline \multicolumn{7}{|c|}{ Do you go online daily? } \\
\hline & \multicolumn{2}{|c|}{ UMES } & \multicolumn{2}{|c|}{ Howard } & \multicolumn{2}{|c|}{ COMBINED } \\
\hline Yes & 197 & $85 \%$ & 78 & $99 \%$ & 275 & $89 \%$ \\
\hline No & 34 & $15 \%$ & 1 & $1 \%$ & 35 & $11 \%$ \\
\hline Total & 231 & $100 \%$ & 79 & $100 \%$ & 310 & $100 \%$ \\
\hline
\end{tabular}

Institutional comparison with respect to the four questions represented in Tables 3 and 4 were examined and were shown to support hypothesis 2 . The analysis supported the hypothesis.

$\mathrm{h}_{2}$ : Students attending a private minority serving institution have greater ownership of, and access to, technology.

When asked to rank themselves as a computer user, most students said that they were either intermediate users $(50 \%)$ or somewhat experienced $(40 \%)$. The Howard University students indicated slightly more confidence with their computer skills than did the UMES students. These results are shown in Table 5.

\begin{tabular}{|l|c|c|c|c|c|c|}
\hline \multicolumn{7}{|c|}{ Table 5: Please rank yourself as a computer user: } \\
\hline & \multicolumn{2}{|c|}{ UMES } & \multicolumn{2}{c|}{ Howard } & \multicolumn{2}{c|}{ COMBINED } \\
\hline $\begin{array}{l}\text { Virtually A Nov- } \\
\text { ice }\end{array}$ & 16 & $7 \%$ & 6 & $8 \%$ & 22 & $7 \%$ \\
\hline Some Experience & 102 & $44 \%$ & 21 & $27 \%$ & 123 & $40 \%$ \\
\hline Intermediate & 105 & $45 \%$ & 50 & $63 \%$ & 155 & $50 \%$ \\
\hline Expert & 8 & $3 \%$ & 2 & $3 \%$ & 10 & $3 \%$ \\
\hline Total & 231 & $100 \%$ & 79 & $100 \%$ & 310 & $100 \%$ \\
\hline
\end{tabular}

Both groups of students were asked how they selected their major. Gathering this information is important when schools want to consider recruitment approaches most likely to be effective. The most common response from the participating students was input from family $(25 \%)$. All responses are represented in Table 6 . 


\begin{tabular}{|l|c|}
\hline \multicolumn{2}{|c|}{ Table 6: How did you select your major } \\
(select all that apply)?
\end{tabular}

Most students (65\%) said that when applying to college they DID NOT consider a major dealing with computers and $28 \%$ replied that they DID consider a computer related major. These results were similar across institutions and are represented in Table 7.

\begin{tabular}{|l|c|c|c|c|c|c|}
\hline \multicolumn{7}{|c|}{ Table 7: Did you consider a college major dealing with computers? } \\
\hline & \multicolumn{2}{|c|}{ UMES } & \multicolumn{2}{c|}{ Howard } & \multicolumn{2}{c|}{ COMBINED } \\
\hline Yes & 64 & $28 \%$ & 23 & $29 \%$ & 87 & $28 \%$ \\
\hline No & 157 & $67 \%$ & 51 & $65 \%$ & 202 & $65 \%$ \\
\hline Other & 10 & $5 \%$ & 4 & $6 \%$ & 14 & $5 \%$ \\
\hline Total & 231 & $100 \%$ & 78 & $100 \%$ & 309 & $100 \%$ \\
\hline
\end{tabular}

The students at the University of Maryland Eastern Shore were asked a follow up question to determine the reasons why they did not choose to pursue computers as a field of study. The most popular reasons cited for not studying computers were that they did not think that their computer skills were strong enough (25\%), they would not like the work (24\%), they thought it would be too hard (22\%), and/or that it would be too technical (20\%) (see Table 8$)$.

\begin{tabular}{|l|c|}
\hline \multicolumn{2}{|c|}{$\begin{array}{c}\text { Table 8: I considered a computer related major but did } \\
\text { not pursue it because (select all that apply) }\end{array}$} \\
\hline My computer skills are not good enough & $25 \%$ \\
\hline I did not think that I would like the work & $24 \%$ \\
\hline I thought it would be too hard & $22 \%$ \\
\hline I thought it would be too technical & $20 \%$ \\
\hline $\begin{array}{l}\text { I could not find enough information about } \\
\text { computer careers }\end{array}$ & $14 \%$ \\
\hline Computer classes are boring & $11 \%$ \\
\hline Other & $11 \%$ \\
\hline
\end{tabular}


The literature claims that women and minorities are not being counseled about computer-related disciplines (Chute, 2009; Delos, 2008; NSF, 2005). Students at both schools, and at about the same percentage, said that they were NOT counseled about computer related careers in high school (73\%) or when they arrived at the University (74\%). These results are shown in Table 9.

\begin{tabular}{|c|c|c|c|c|c|c|}
\hline \multicolumn{7}{|c|}{ Table 9: Counseling } \\
\hline \multicolumn{7}{|c|}{ I was counseled about computer related careers in high school } \\
\hline & \multicolumn{2}{|c|}{ UMES } & \multicolumn{2}{|c|}{ Howard } & \multicolumn{2}{|c|}{ COMBINED } \\
\hline Yes & 64 & $28 \%$ & 20 & $26 \%$ & 84 & $27 \%$ \\
\hline No & 168 & $72 \%$ & 58 & $74 \%$ & 226 & $73 \%$ \\
\hline Total & 232 & $100 \%$ & 78 & $100 \%$ & 310 & $100 \%$ \\
\hline \multicolumn{7}{|c|}{$\begin{array}{l}\text { I was counseled about computer related careers when I arrived at this univer- } \\
\text { sity. }\end{array}$} \\
\hline & \multicolumn{2}{|c|}{ UMES } & \multicolumn{2}{|c|}{ Howard } & \multicolumn{2}{|c|}{ COMBINED } \\
\hline Yes & 50 & $22 \%$ & 30 & $38 \%$ & 80 & $26 \%$ \\
\hline No & 181 & $78 \%$ & 48 & $62 \%$ & 229 & $74 \%$ \\
\hline Total & 231 & $100 \%$ & 78 & $100 \%$ & 309 & $100 \%$ \\
\hline
\end{tabular}

The questions represented in Table 9 supported the third hypothesis considered in this study.

$\mathrm{h}_{3}$ : Minority students are not counseled about computer related majors prior to college.

The UMES students were also asked follow up questions that examined their level of knowledge. The students indicated either minimal or a lack of knowledge with respect to college majors in CS, IS, or related disciplines. These results are indicated in Table 10. 
Table 10: Knowledge

\begin{tabular}{|c|c|c|c|c|c|}
\hline \multicolumn{3}{|c|}{ College Major in Computer Science } & \multicolumn{3}{|c|}{ Careers for Computer related majors } \\
\hline None & 59 & $26 \%$ & None & 48 & $21 \%$ \\
\hline Minimal & 107 & $47 \%$ & Minimal & 111 & $49 \%$ \\
\hline Moderate & 58 & $25 \%$ & Moderate & 61 & $27 \%$ \\
\hline Significant & 5 & $2 \%$ & Significant & 8 & $4 \%$ \\
\hline Total & 229 & $100 \%$ & Total & 228 & $100 \%$ \\
\hline \multicolumn{3}{|c|}{ College Major in Information Systems } & \multicolumn{3}{|c|}{ College major in other computer related fields } \\
\hline None & 82 & $36 \%$ & None & 63 & $27 \%$ \\
\hline Minimal & 98 & $43 \%$ & Minimal & 97 & $42 \%$ \\
\hline Moderate & 43 & $19 \%$ & Moderate & 65 & $28 \%$ \\
\hline Significant & 6 & $3 \%$ & Significant & 5 & $2 \%$ \\
\hline Total & 229 & $100 \%$ & Total & 230 & $100 \%$ \\
\hline \multicolumn{3}{|c|}{$\begin{array}{l}\text { Difference between Computer Science and } \\
\text { Information Systems }\end{array}$} & \multicolumn{3}{|c|}{ Using Computers in general } \\
\hline None & 97 & $43 \%$ & None & 2 & $1 \%$ \\
\hline Minimal & 86 & $38 \%$ & Minimal & 27 & $12 \%$ \\
\hline Moderate & 41 & $18 \%$ & Moderate & 119 & $52 \%$ \\
\hline Significant & 3 & $1 \%$ & Significant & 81 & $35 \%$ \\
\hline Total & 227 & $100 \%$ & Total & 229 & $100 \%$ \\
\hline
\end{tabular}

\section{Phase 2}

In the second phase of the study, Howard University declined to participate further. An opinion survey was administered to students majoring in computer science at the University of Maryland Eastern Shore. The survey was administered using an online survey tool and an email was sent to all 83 computer science majors. Fifty-two responded, a $61 \%$ response rate. Students represented all academic years with $39 \%$ freshmen, $20 \%$ sophomore, $17 \%$ junior, and $24 \%$ seniors. There were more male respondents (59\%) than female respondents, which is almost the opposite ratio of the larger university student population where females outnumber males. At the same time, it is indicative of the scarcity of females in computer science majors across the nation (Clinging, 2006).

Prior experience studying computing was considered. Most students (67\%) said that they studied computers in high school. This was oddly lower than what was reported in Phase One of the study, when the average was $78 \%$. This may indicate that the non-CS students were more likely to have studied computers before coming to college then students who ended up majoring in CS. Another possibility is that CS students view the study of computers differently than non-CS majors. 
Wallace and Clariana (2005) found that students often come to college lacking the skills necessary to succeed in computing majors and Buzzetto-More and Sweat-Guy (2007) found that minority-students are less likely to have studied computing before coming to college. As a result, when the students were asked whether they had experience with computer programming before coming to college and only $42 \%$ responded in the affirmative, the results were not surprising. Finally, about half the students (48\%) said that they were counseled about computer related careers when they arrived at the University. Table 11 presents the responses to the Yes/No questions.

\begin{tabular}{|l|l|l|}
\hline \multicolumn{1}{|c|}{ Table 11: Yes/No Responses (All Students) } & Yes & No \\
\hline Did you study computers in high school? & $67 \%$ & $33 \%$ \\
\hline Did you have experience with computer programming before college? & $42 \%$ & $58 \%$ \\
\hline $\begin{array}{l}\text { I was counseled about computer related careers when I arrived at this } \\
\text { university? }\end{array}$ & $48 \%$ & $52 \%$ \\
\hline
\end{tabular}

The literature has claimed that women face biases and low expectations with respect to computing disciplines (Clinging, 2006). As a result, the responses of the female participants were considered separately. When the questions were examined double digit differences were found. According to the results, women were less likely to report that they had studied computers in high school, had experience with programming before college, and/or had been counseled about computer related careers (see Table 12). These responses were used to consider the fourth hypothesis and were found to support the hypothesis.

h4: Females students attending a minority-serving institution have less prior exposure to, and counseling about, computing than males.

\begin{tabular}{|l|l|l|}
\hline \multicolumn{1}{|c|}{ Table 12: Female Responses to Yes/No } & Yes & No \\
\hline Did you study computers in high school? & $57 \%$ & $43 \%$ \\
\hline Did you have experience with computer programming before college? & $30 \%$ & $70 \%$ \\
\hline $\begin{array}{l}\text { I was counseled about computer related careers when I arrived at this } \\
\text { university? }\end{array}$ & $88 \%$ & $62 \%$ \\
\hline
\end{tabular}

Many people have speculated about the reasons students do not persist in computing-related majors; however, studies have failed to pose this question to students. When the participants were asked to respond to the statement, "If you are, or have considered, switching majors please tell us why," the most common response was that their computer/programming skills are inadequate (73\%). Table 13 presents all of the responses expressed. 


\begin{tabular}{|c|c|}
\hline \multicolumn{2}{|c|}{$\begin{array}{l}\text { Table 13: If you are (or have considered) switching ma- } \\
\text { jors please tell us why (select all that apply) }\end{array}$} \\
\hline This major is too focused on programming & $7 \%$ \\
\hline I do not like the courses & $60 \%$ \\
\hline I am not satisfied with the instructors & $47 \%$ \\
\hline Quality of degree program & $33 \%$ \\
\hline $\begin{array}{l}\text { I prefer information systems over computer sci- } \\
\text { ence }\end{array}$ & $13 \%$ \\
\hline Computer classes are boring & $0 \%$ \\
\hline The classes are too hard & $20 \%$ \\
\hline $\begin{array}{l}\text { My computer/programming skills are not good } \\
\text { enough }\end{array}$ & $73 \%$ \\
\hline $\begin{array}{l}\text { People who work in computer related careers are } \\
\text { strange }\end{array}$ & $0 \%$ \\
\hline All computer industry jobs are overseas & $0 \%$ \\
\hline The employment prospects are not good & $0 \%$ \\
\hline I do not own a good computer & $7 \%$ \\
\hline
\end{tabular}

The participants were asked to rank their computer programming skills, with most saying they had some experience (49\%), 24\% responding that they are virtually a novice, $24 \%$ considering themselves to be intermediate programmers, and $4 \%$ considering themselves to be experts. The responses were the same for both the male and female respondents. These results affirm what has been found in the literature.

The students were also asked to rank their computer application skills. They indicated greater confidence in their computer application skills than in their programming skills. The results are shown in Figure 1.

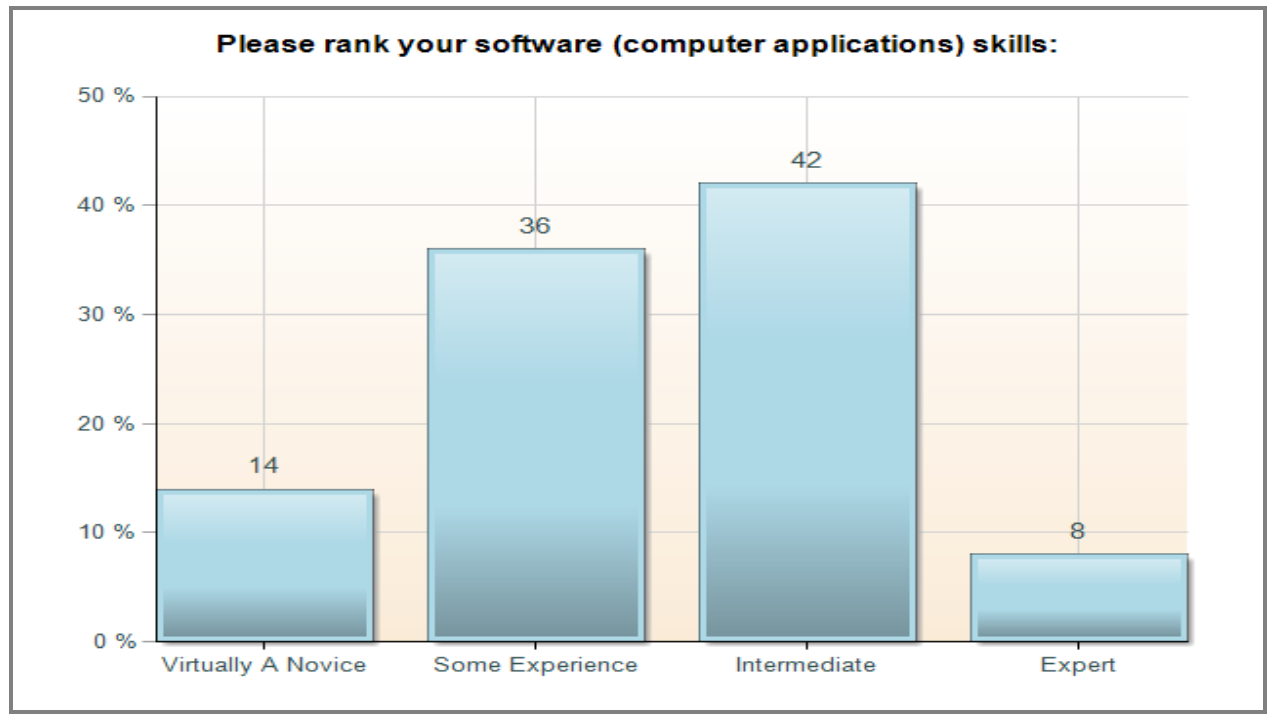

Figure 1: Application Skills 
Preparedness for college was explored. The students were asked whether they came to college with the computer skills that they needed to succeed as a CS major. In response, $35 \%$ agreed/strongly agreed, $31 \%$ expressed neutrality, and 35\% either disagreed or strongly disagreed. These results affirmed the literature and are shown in Figure 2. Additionally, when the same question was asked of the female respondents, the results were almost identical. These responses supported the fifth hypothesis considered in this study.

$\mathrm{h}_{5}$ : College students attending a minority serving institution do not come to college prepared for success as a computing major.

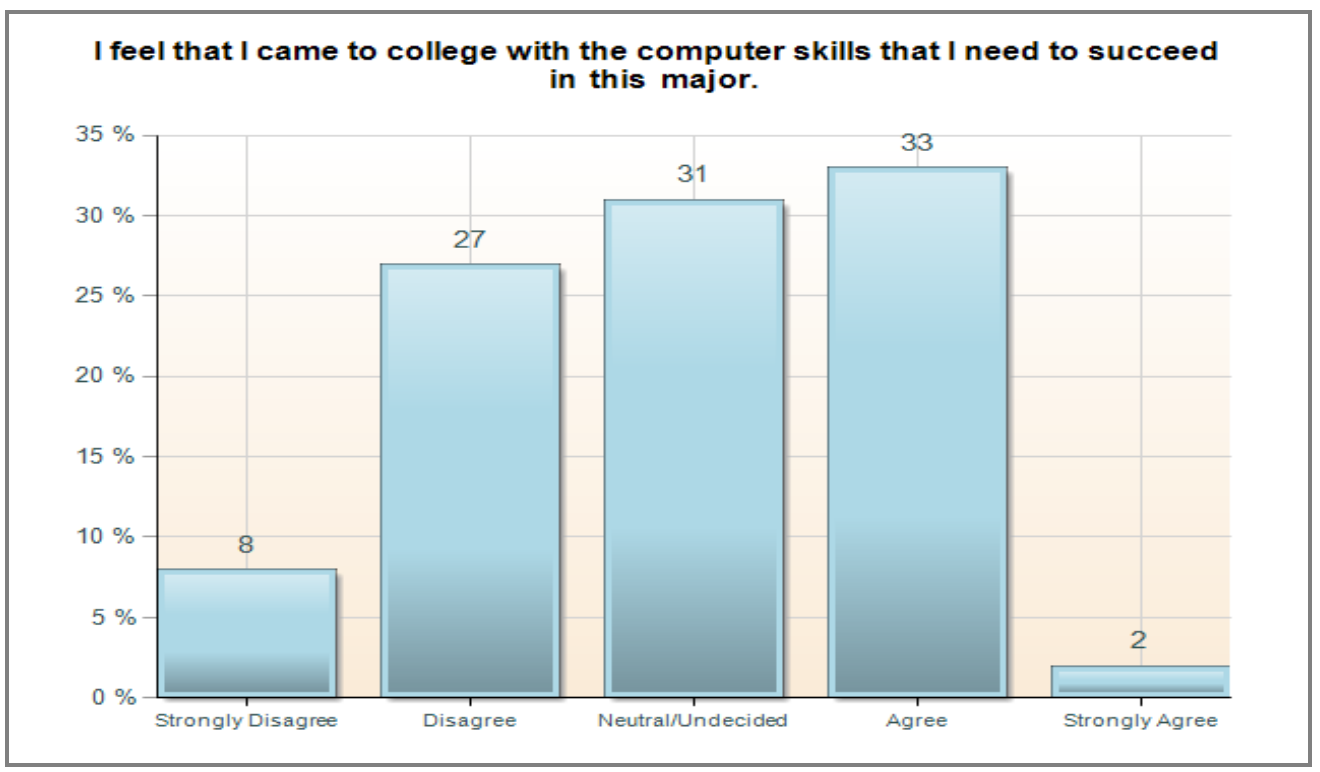

Figure 2: Preparedness

\section{Phase 3}

In the third phase of this study, a focus group was held with junior and senior computer science students at the University of Maryland Eastern Shore. In total, there were 15 participants. Thirteen of the respondents were male and two were female.

The participants were asked whether they were prepared when they entered the CS program to succeed in their classes. Four responded that they were prepared and the remaining 9 responded that they were not prepared. When asked what could have made them more prepared the most common response was experience studying computer programming prior to entering the university. Other responses included: "I had no idea what to expect or how to prepare" and "I had to take remedial math, which made me behind in my classes."

The students were asked if they had studied programming prior to entering the CS program. Only 4 students had studied programming prior to attending college; however, 13 out of 15 students had taken computer applications courses prior to coming to college. All of the respondents agreed that high schools are not offering the right courses to prepare future computer science majors for academic success.

The participants were also asked, "What can schools do to entice more girls and minoritystudents into computer science majors?" There were a variety of responses which included: 
- "introduce a summer program with programming and introductory math classes to be taken by freshmen before the fall begins",

- " add an information systems degree",

- "have more relation to real world usage",

- "need better trained high school teachers teaching computing classes",

- "offer more fun programs like game or Web design",

- "more emphasis on the importance of foundations".

Participants were asked to offer suggestions for getting more girls and minorities to become, and remain, computer science majors. The suggestions included:

- "visit high schools",

- "tell kids what CS is about",

- "offer summer programs",

- "require fewer math classes",

- "work with high schools to develop courses",

- "support students better when they get in the program",

- "have courses available the summer before freshmen year",

- "offer a pre-programming or a programming fundamentals classes",

- "offer more scholarships"

\section{Contributions and Study Limitations}

This study provides research on a population that has previously not received sufficient focus. Whereas a handful of studies have been conducted at majority institutions, this is the first study of this size and magnitude that has been conducted at Historically Black Colleges and/or Universities. Examinations conducted at Historically Black Colleges and/or Universities are important because the critical mass of African American college students can be found at HBCUs, which represent less than $3 \%$ of U.S. colleges and universities but enroll $28 \%$ of all African American college students and graduate $40 \%$ of the African Americans who earn doctorates or first professional degrees (Hubbard, 2006).

The most significant limitation of this study is that it focused solely on participants attending minority-serving institutions. It currently does not include data acquired at a majority institution for comparison. Additionally, when conducting studies at HBCUs, because of their low enrollment of non-Blacks, comparisons between racial groups cannot be made with validity.

\section{Conclusions}

This paper presents the results of a three phased multi-methodology study. This findings suggest that poor advisement about CS and IS majors, a lack of experience studying computing prior to college, and a lack of exposure to programming are a hindrance to under-represented student enrollment, success, and retention in CS and IS majors.

Phase 1 of the study looked at non CS/IS students enrolled in intermediate computer applications courses at two HBCUs. The findings supported the all three hypotheses tested illustrating that higher socio-economic status among minority learners correlates to a greater computer ownership 
and training; however, regardless of institutional type, minority students lack the proper knowledge necessary to select a computing major.

h1: students attending a private minority-serving institution are more likely to come to college having previously studied computing then students enrolled at a public minority serving institution,

h2: students attending a private minority-serving institution have greater ownership of, and access to, technology, and

h3: minority students are not counseled about computer related majors prior to college,

In Phase 2, a survey was administered CS majors attending a public HBCU. The findings supported the two hypotheses tested. The fist hypothesis affirmed that female students are less likely to have exposure to computing prior to attending college and that both female and male students attending a minority-serving institution do not come to college prepared for success.

$\mathrm{h} 4$ : female students attending a minority-serving institution have received less exposure to, and counseling about, computing than males.

h5: students attending a minority serving institution do not come to college prepared for success as a computing major.

In Phase 3 of this study, a focus group was held with CS majors. The participants offered suggestions for getting more females and minorities to become, and remain, CS majors. The suggestions included: the development of partnerships between high schools and colleges for recruitment visitations and course development; the introduction of pre-college preparatory programs, also referred to as bridge programs; increased scholarship opportunities; and the availability of more academic support to students enrolled in undergraduate CS/IS programs.

The study reported in this paper is unique in its scope, focus, and population. Larger studies of this kind need to be conducted at additional minority serving and/or female dominated institutions. The information gained from these studies should be used to design and introduce more initiatives that seek to address the under representation of women and minorities in computing. Additionally, a better understanding of the state of computing education in American high schools needs to be gained. As a result, the next phase of this project will examine the course offerings and advising techniques in both majority and minority dominated high schools in Maryland and the District of Columbia.

\section{References}

Ami, C. G. (2001). The effects of a four-week summer bridge program. Washington D.C.: U.S. Department of Education: Office of Educational Research and Improvement.

Buzzetto-More, N., \& Sweat-Guy, R. (2007). Digital natives: Exploring the technology experiences and uses of the millennium generation. Journal of Global Information Technology, 1(12), 78-87.

Chute, E. (2009). Lack of diversity part of equation in STEM fields. Colleges try to increase numbers of women, minorities in science and engineering. Pittsburgh Post-Gazette. Retrieved 2/21/10 from http://www.post-gazette.com/pg/09041/947952-298.stm\#ixzz0g1ceZiGK

Clinging, D. (2006). Fostering computer science success among women and minorities. Magazine of the Society of Women Engineers, (May/June), 38-41

Delos, R. (2008). New study examines diversity in STEM fields. Diverse: Issues In Higher Education. Retrieved 22/11/10 from http://diverseeducation.com/artman/publish/article_11722.shtml

Hubbard, D. (2006). The color of our classroom, the color of our future. Academe, 92(6), 27-29. 
Lazowska, D. E., (1999). Commission on the advancement of women and minorities in science, engineering, and technology development. Computing Research Association. Retrieved April 12, 2009 from: http://www.cra.org/Policy/testimony/lazowska-5.html

Morgan, J., \& VanLengen, C. (2005). The digital divide and K-12 student computer usage. Issues in Informing Science and Information Technology, 2, 705-724.

National Science Foundation. (2005). Pathways to STEM careers, Final workshop report, 2005. NSF, Arlington, VA.

Nealy, M. (2007). Study: Minority faculty severely underrepresented in Top 100 STEM departments. $D i$ versity Education. Retrieved 2/11/10 from http:/diverseeducation.com/article/9971/1.php

Orama, R. (2002). Increase retention rates in computer science, engineering with a wireless classroom at UPRM. International Conference on Engineering Education. August 18-21, 2002, Manchester, U.K.

Sax, L., Ceja, M., \& Teranishi, R. (2001). Technological preparedness among entering freshmen: The role of race, class, and gender. Journal of Educational Computing Research, 24(4), 363-383.

U.S. Department of Labor Bureau of Labor Statistics. (2005). Occupational outlook handbook, 2006-2007 edition. U.S. Department of Labor, Washington, D. C. Retrieved April 12, 2009 from: http://www.bls.gov/oco/ocos042.htm

University of California Santa Cruz Basking College of Engineering. (2005). Summer Bridge Program prepares incoming engineering students. Retrieved 6/7/09 from http://www.soe.ucsc.edu/news/article?ID=1153

Wallace, P., \& Clariana, R. (2005). Perception versus reality-Determining business students' computer literacy skills and need for instruction in information concepts and technology. Journal of Information Technology Education, 4, 141-151. Retrieved from http://www.jite.org/documents/Vol4/v4p141151Wallace59.pdf

Young, J. (2004, November 12). Testing service to unveil an assessment of computer and information literacy. The Chronicle of Higher Education, 51(12), 33.

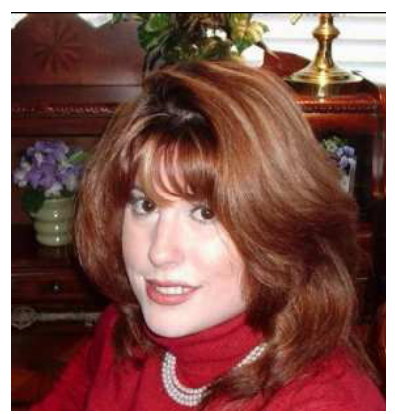

\section{Biographies}

Dr. Nicole A. Buzzetto-More is an Associate Professor in the Department of Business at the University of Maryland Eastern Shore and Co-Founder of the UMES Office of Instructional Technology. She is also a Fellow of the Informing Science Institute. She received her doctorate from Columbia University and masters and bachelors degrees from Columbia University, the College of New Rochelle, and Marist College. She has served as the editor of two e-learning books published in 2007, has contributed several book chapters, is on the editorial board of a number of journals, and has authored numerous publications in referred journals. She has been recognized with awards from the American Distance Education Consortium, the Global Digital Business Association, and the Informing Science Institute. Her third book The E-Portfolio Paradigm: Informing, Educating, Assessing, and Managing with E-Portfolios was published in the spring of 2010 by the Informing Science Press. 


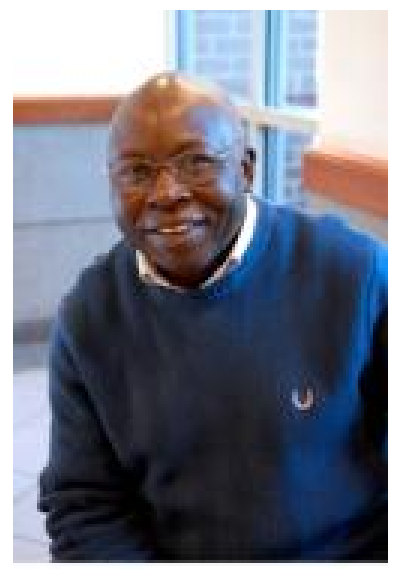

Dr. Ojiabo Ukoha is a Lecturer in the Department of Mathematics and Computer Science at the University of Maryland Eastern Shore. He received his doctorate from the UMES in Organizational Leadership and holds an M.B.A. from Kennesaw State College and an M.S. from Clark Atlanta University. His research interests include the infusion of technology into mathematics instruction, the retention of first generation and low-income students in higher education, and recruiting and retaining students in computer science and other STEM disciplines.

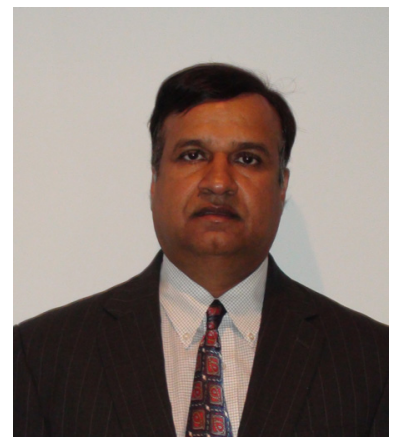

Dr. Narendra Rustagi is the Father of Distance Education at Howard University. He earned his doctorate from Ohio State University in Agricultural Economics and Quantitative Techniques. He is the chair of Information Systems and Analysis in the School of Business at Howard University. Dr. Rustagi also co-chaired Howard's Distance Education Task Force, setting policies that safeguard the academic integrity of distance-ed programs. Moreover, he has received several grants to develop distance education, as well as, served as Director of Howard's online MBA program in e-Commerce. 